\title{
TOWARDS A REAL ESTATE REGISTRY 3D MODEL IN PORTUGAL: SOME ILLUSTRATIVE CASE STUDIES
}

\author{
J.-P. de Almeida $^{\text {a, b,c }} *$, C. Ellul ${ }^{\text {c }}$, M. M. Rodrigues-de-Carvalho ${ }^{d}$ \\ ${ }^{a}$ Geomatic Engineering Lab., Dept. of Mathematics, Faculty of Science \& Technology, University of Coimbra, Apartado 3008, \\ 3001-501 Coimbra, Portugal - zepaulo@mat.uc.pt \\ ${ }^{\mathrm{b}}$ Institute for Systems Engineering \& Computers at Coimbra, Rua Antero de Quental 199, 3000-033 Coimbra, Portugal \\ ${ }^{c}$ Dept. of Civil, Environmental \& Geomatic Engineering, University College London, Gower Street, London WC1E 6BT, UK - \\ c.ellul@ucl.ac.uk \\ ${ }^{\mathrm{d}}$ Coimbra City Council, Cadastre \& Land Management Office, Pátio da Inquisição 7, 3000-221 Coimbra, Portugal - \\ maria.manuel@cm-coimbra.pt
}

\section{Commission III WGIII/4}

KEY WORDS: 3D cadastral modelling, 3D property unit, 3D multipurpose cadastre.

\begin{abstract}
:
The 3D concept emerged as a key concept within geoinformation science. 3D geoinformation has been proved to be feasible and its added value over 2D geoinformation is widely acknowledged by researchers from various fields. Even so, 3D concept merits still need to be exploited further and more specific applications and associate products are needed - such as within real estate cadastre, our ultimate field of interest. The growing densification of urban land use is consequently increasing situations of vertical stratification of ownership rights. Traditional 2D cadastral models are not able to fully handle spatial information on those rights in the third dimension. Thus, 3D cadastre has been attracting researchers to better register and spatially represent real world overlapping situations. A centralised distributed cadastral management system, implementing a 2D cadastral model, has been conceived by the national cadastral agency in Portugal: the so-called SiNErGIC. The authors seek to show with this paper that there is room though for further investigation on the suitability of a $3 \mathrm{D}$ modelling approach instead, which should not be confined only to topologicalgeometric representations but should also be extended in order to be able to incorporate the legal/administrative component. This paper intends to be the first step towards the design of a prototype of a 3D cadastral model capable of handling the overall multipurpose cadastral reality in Portugal; it focuses primarily on the clear identification of some case studies that may illustrate the pertinence of such an approach in the context of this country.
\end{abstract}

\section{INTRODUCTION}

\subsection{General context: 3D geoinformation}

Most information needed by policymakers is related to locations on the Earth. Despite some practical difficulties, it is clear that 3D geoinformation is becoming increasingly important. Research has demonstrated the added value of 3D information over 2D in these cases: an overall more efficient integration of urban vs. regional planning and management especially dealing with 3D underground/aboveground infrastructures.

There has been consistent research within geoinformation science on the concept of 3D for more than a decade now. For instance, merits of 3D GIS techniques have been widely debated, tested, and have been proved to be quite advanced. Nevertheless, several individual parties potentially involved are still reluctant to invest in 3D data, 3D techniques, and applications. As a consequence, large administration processes relating to urban/rural planning often run up financial losses simply because geoinformation is not part of the process.

In spite of all the research undertaken, 3D geoinformation is a complex field and requires more advanced research and techniques to be especially used in complex administrative procedures (Stoter, 2011). In addition, more specific applications and associate products are needed. Geoinformation science is never a goal in itself, it is a "serving discipline", and without applications it may well turn useless (Stoter, 2011). Examples include: automated change detection; integration of voxel and 3D vector data; generation, from laser-scanned point data, of tree and/or building models, which can be easily integrated in OGC CityGML models; interactive airstream simulations; 3D city models; integrated geospatial planning and management of 3D underground/aboveground municipal assets; or 3D cadastre. 3D cadastre - in fact, our ultimate field of interest - certainly has to build on 3D geoinformation science: 3D GIS as a whole, 3D geospatial data, 3D topology, and 3D data-structures. Even so, there is the need to take it further in order to tackle specific needs and to be able to incorporate cadastral laws.

\subsection{Motivation}

Regardless of the country, federal state, or province, an up-todate property cadastral system is fundamental for a sustainable development and environmental protection. It is indeed widely acknowledged to be the basis of a healthy economy, and hence the pertinence of such topic.

\footnotetext{
* Corresponding author
} 
Current worldwide property cadastral registries use 2D parcels to register ownerships rights, limited rights, and public law restrictions on land. In most cases this is sufficient to give clear information about the legal status of real estate. But in cases of multiple use of space, with stratified property rights in land, the traditional 2D cadastre is not, or only in a limited way, able to reflect the spatial information about those rights in the third dimension. As a matter of fact, the growing density of land use in urban context is consequently increasing situations of vertical demarcation between real estate properties. Thus, 3D cadastre has been attracting researchers through out the world for nearly a decade now to better register and spatially represent real world overlapping situations.

As far as Portugal is concerned, a centralised distributed cadastral management system, which implements a 2D cadastral model, has been conceived: the so-called SiNErGIC. Nevertheless, its technical implementation is far from being concluded mainly because most of surveyed geospatial data, referring to coordinated cadastre, is still being acquired in the field and processed. Moreover, from several experiences across the world it is known beforehand that a $2 \mathrm{D}$ model has limitations for it is not capable of modelling and handling very well complex 3D situations.

Every standard is generic in nature. Thus, the recently approved international standard ISO 19152 (November $1^{\text {st }}, 2012$ ) should be adapted to Portugal's cadastral reality. The standard model has to be conveniently applied in order to incorporate Portuguese Cadastral Law. The ultimate goal should be the implementation of a 3D cadastral model capable of handling the overall cadastral reality in Portugal. Ideally, further agreements between many stakeholders - ranging from governmental bodies, research centres, to commercial parties - should be achieved to assure optimal operability of such a model. As a result of such a nationwide agreement, a 3D national standard for large-scale topography should be set up.

\subsection{Aim and objectives}

In the light of the above, an investigation of 3D cadastre aspects appears to be pertinent both in the context of the Portuguese real estate law as well as in its geometrical side. The main aim of this research report is to discuss the pertinence of such an investigation and launch its bases. Some objectives were identified as follows:

- To start with, the review of both some historical circumstances and current status of the Portuguese property cadastre;

- Secondly, to review literature on related work covering 3D spatial data-structures, 3D GIS, and 3D cadastral approaches;

- Also, in order to illustrate the pertinence of a 3D cadastre approach, the identification of some instances where the current 2D cadastral model in Portugal is limited;

- Finally, to draw recommendations with regards to the next investigation steps.

\section{PORTUGAL'S REAL ESTATE CADASTRE REVISITED}

\subsection{Some elementary cadastral concepts and definitions}

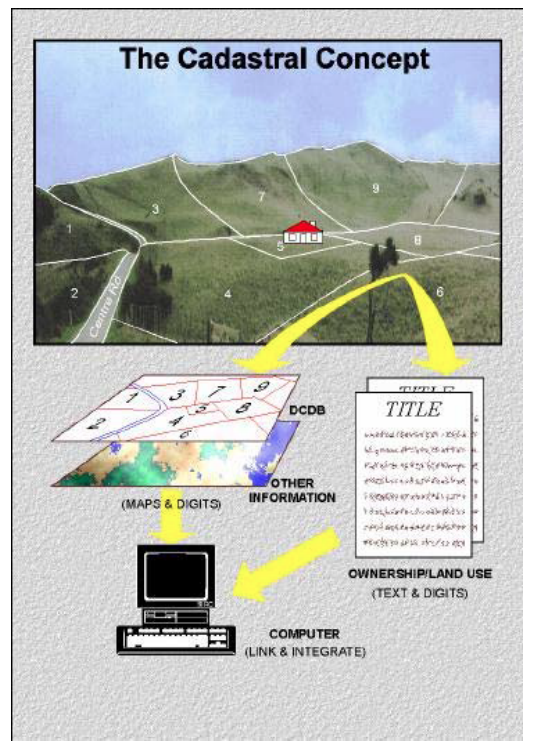

Figure 1. The overall concept of a cadastral system (FIG, 1995).

Property cadastre information is usually managed by one or more government agencies. The central defining feature of any land management system is a property cadastre that states the record of all interests associated to land, describing in particular the rights, restrictions and responsibilities (RRR) (Figure 1). A cadastral system may be established principally for three somewhat traditional purposes or functions (FIG, 1995):

- Fiscal, e.g. valuation and equitable taxation;

- Legal, mainly in the support of legal transactions (conveyance),

- Territory management, e.g. to assist in urban/regional planning or other administrative purposes.

Regardless of being $2 \mathrm{D}$ or $3 \mathrm{D}$, a cadastre is normally a land lotbased system, i.e. information is geographically referenced to unique, well-defined units of land - the so-called parcels. These parcels are defined by the formal or informal boundaries marking the extent of lands held for exclusive use by individuals or specific groups of individuals (e.g. families, inheritances, corporations, or any other communal groups). Graphical indices of these parcels, known as cadastral maps, show the relative location of all parcels in a given region. Cadastral maps commonly range from scales of 1:10 000 to 1:500. Large-scale diagrams or maps showing more precise parcel dimensions and features (e.g. buildings, irrigation units, etc.) can be compiled for each parcel based on ground surveys or remote sensing and aerial photography. Information in the textual or attribute files of the cadastre, such as land value, ownership, or use, can be accessed by the unique parcel code shown on the cadastral map, thus creating a complete cadastre (FIG, 1995).

\subsection{Historical aspects and current status}

The first official step towards the establishment of a national registry of land parcels in Portugal was taken in 1801. By royal 
decree, all cosmographers ${ }^{1}$ of the kingdom were appointed then to be in charge of the organisation of both a cadastre and a general registry book of all real estates existing in the kingdom. The fact that those practitioners were the ones in charge of accomplishing such a task, clearly states how aware authorities were in those days of the great value of a coordinated cadastre. For several reasons, such a registry was never launched though until 1836, when the national real estate registry (Registo Predial) actually started being implemented (Silva et al., 2005). Like in many other countries across the world, the Portuguese real estate registry system is based on the "folio principle", i.e. each "land parcel" on the ground is related to exactly one ownership title registered in the land registry. Every land parcel has a unique parcel identifier number to which all parcelrelevant information is linked. The term "property" as such is not used in the Portuguese legislation, though the equivalent word does exist in Portuguese, propriedade, but is more informally used in everyday language. The official term used, as explained below, is prédio ${ }^{2}$.

Like other property parcel registries across the world, Registo Predial has been serving in Portugal as the pillar foundation for property transactions and for securing the legal status of property boundaries. Even though the registration of real estates has been in theory mandatory since the registry was launched, in practical terms this was not really the case unless any legal transaction over a given parcel was in fact to be undertaken. In general, however, real estates in Portugal are historically likely to be passed on through generations by simply being inherited. They would be rarely sold/bought and it was not indeed until roughly the 1980 s that such transactions became more common. As a consequence, many real estates are still omitted from the registry. Portuguese authorities are however somewhat in control of the situation for the national revenue and customs agency $\left(\mathrm{ATA}^{3}\right)$ is in charge of up-to-date records for taxation purposes (the so-called Matriz Predial) on the nearly 17 million real estates in the country.

Thus, the national records on real estates in Portugal are nowadays spread throughout two different databases: Registo Predial (set up for legal purposes) and Matriz Predial (set up for taxation purposes).

Like other cadastres across the world, Portugal's cadastre also follows a real estate-based approach. In the Portuguese jurisdiction, real estates (prédios) can be classified into one of the three following possible types (Mendes, 2003):

- Rural (prédio rústico) - which may be situated either in rural or urban areas. The main characteristic of this type of real estates is that they are not meant to be subjected to any sort of construction development, and hence are principally devoted to agriculture or forestry activities. Besides land lots, this parcel type may also include water bodies and crops (separate from the land lot where they happen to lie on).

- Urban (prédio urbano) - which are situated only within urban areas only. This type of real estates includes any manmade construction (i.e. meant for residential, commerce, industrial or services purposes), and may also include land lots meant to be developed.

\footnotetext{
${ }^{1}$ One who studies, describes, depicts, and measures the Earth and/or the visible universe, including geography and astronomy.

2 From the Latin word prcedium, standing for "real estate" or "legal immovable property" unit.

${ }^{3}$ Autoridade Tributária e Aduaneira.
}

- Mixed (prédio misto) - Although rare, this is a very specific type to classify those real estates that have both rural and urban characteristics and none of them can be identified as the main one.

Since both national records were implemented, cadastral information of both Registo Pedrial and Matriz Predial is based on text. Each real estate is geo-referenced by explicit reference to its northern, southern, eastern and western neighbouring parcels or geospatial features (e.g. roads, railways, water bodies, etc.). This is what actually still happens in most instances, as the coordinated cadastre is currently still being surveyed. Cadastral survey was launched in 1926 by the national mapping \& cadastral agency $\left(\mathrm{IGP}^{4}\right)$ and has not covered the whole country yet. It has been indeed a rather complex and demanding operation to undertake given Portugal's territory tissue: a country of a few millions of literally microscopic real estates, especially in the mainland's northern-half, also in Azores and Madeira archipelagos. Figure 2 and Figure 3 below illustrate respectively examples of a cadastral section map produced in the early $20^{\text {th }}$ century and a more recent general cadastral map digitally produced.

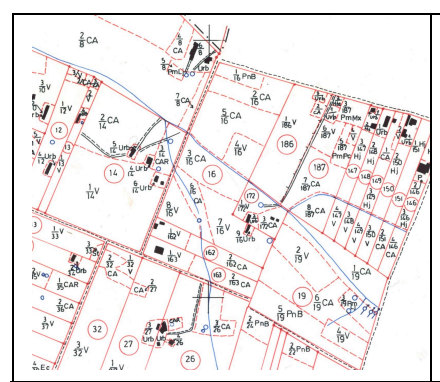

Figure 2 - Map of a cadastral section produced early $20^{\text {th }}$ century (Source: IGP).

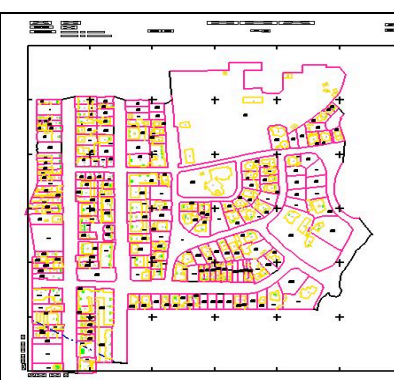

Figure 3 - Cadastral map produced late $20^{\text {th }}$ century (Source: IGP).
Cadastral surveying started off in the mainland's southern-half, where one of the main sources of the country's economy in the first half of the $20^{\text {th }}$ century was: the latifundium ${ }^{5}$. That is why it then only rural real estates; urban real estates were never surveyed until a pilot experiment was carried out between Jan 2006 and Feb 2008 in one of the civil parishes of Pombal district, Albergaria-a-Velha (mainland's west-centre). This was a key step towards cadastre modernisation. Since then, Portugal has embarked on various other initiatives to modernise its cadastral survey. Cadastral surveying is currently being accomplished district-by-district covering both kinds of real estates, rural and urban. As depicted in Figure 4, by the end of 2011 more than $50 \%$ of the mainland's territory had been surveyed, though this only corresponds to roughly $1 / 3$ of the total number of real estates in the country. Currently, 7 districts are being surveyed in Portugal's mainland: Paredes and Penafiel (in the northwest); Oliveira-do-Hospital and Seia (in the centre); Tavira, São-Brás-de-Alportel and Loulé (in the Algarve).

\footnotetext{
${ }^{4}$ IGP - Instituto Geográfico Português.

${ }^{5}$ A large landed farming estate.
} 


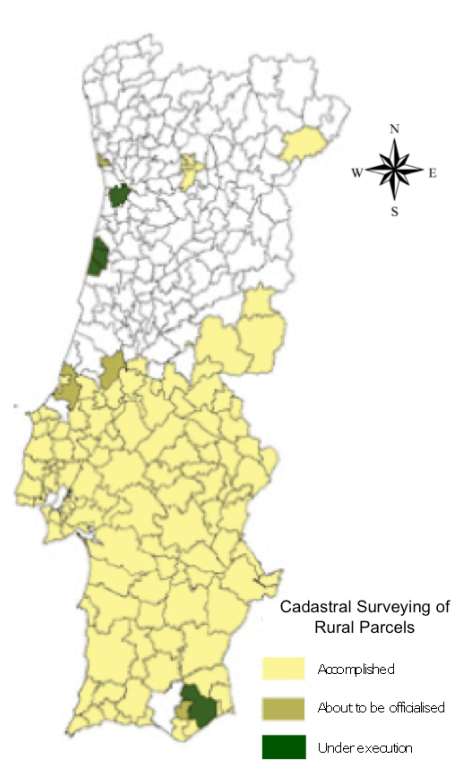

Figure 4. Portugal's mainland districts and progress on cadastral surveying of rural real estates by 2011 (Source: IGP).

\subsection{The future: SiNErGIG}

Overall, property cadastre has been traditionally serving the basis for both taxation and legal purposes. These functions are indeed of most relevance within any country's economy, will not change as such and hence will continue to be significant. A third requirement for cadastre has emerged more recently: urban/regional planning. It is within this context that cadastral survey information became even more crucial. Given its level of detail and amount of data, cadastral survey information constitutes nowadays the most critical land base information to support development and planning in governance (Khoo, 2012).

Aware of the facts above, the Portuguese government took an historical decision in 2006 towards the implementation of a centralised distributed - through the World Wide Web cadastral management system (formalised by Cabinet Resolution nr. 45/2006): the conception and implementation of the so-called SiNErGIC (PCM, 2006). The main goal of such a system is to make available the existence of a multipurpose cadastral system in Portugal setup as an "exhaustive, methodical, and up-to-date set of data able to uniquely identify and describe property parcels" (IGP, 2012).

The main objectives of SiNErGIC can be summarised as follows (PCM, 2006):

- To unify and concentrate within a single system both current and future cadastral data;

- To assure its compatibility with other institutions' electronic systems involved in this project;

- To assure unique identification of each real estate;

- To assure that each real estate's description includes a digital graphical plan;

- To assure its dissemination and usage by general state administration - subject though to specific permissions and protocols;

- To assure both citizens and companies general access to the system - again, subject to specific permissions and protocols.

Because cadastral surveying has been taking so long to cover the whole country, what has actually been happening since the middle 1970s is that several private construction companies and state agencies directly intervening in territorial operations have technically undertaken themselves cadastral surveys as needs arise. In particular, local municipal authorities are in possession of virtually all construction plans within their territorial jurisdiction.

These facts above led recently to a further central government decision, formalised by Cabinet Resolution nr.56/2012 (PCM, 2012a). While formal cadastral surveys are being carried out, other existing cadastral data within both state and private organisations should be centralised in order (PCM, 2012a):

- To be processed and checked against cadastral standards towards its official approval;

- To be articulated and incorporated thereafter within the official source of cadastral survey information.

Further to all governmental decisions above, efforts have also been taken in fact towards existing cadastral data crossing principally from both Registo Predial and Matriz Predial; thus, a merging of both national records is currently ongoing. These cadastral data will be indeed the pillar foundations of the future SiNErGIC.

\section{3D CADASTRE}

\subsection{The need for a 3D cadastral approach}

2D planimetric survey plans have been overall adequate and acceptable to property owners. With increasingly complex developments above and underground - where structures and usage of space cannot be seen in $2 \mathrm{D}$ - this is no longer the case. Even so, one may argue that the question is still open: is there in fact a real need for a 3D model for property cadastre purposes? As far as we are concerned, yes there is. The issue is not so much the need for simple $3 \mathrm{D}$ visualisation capabilities of a stratified reality - though a very much pertinent aspect. It should be emphasised that the real issue dwells in the linkage between a 3D geometry/topology infrastructure and legal concepts on stratified ownerships, which are far less tangible. In other words, the real difficulty is the materialisation of legal concepts that a human eye may well be aware of, but a 2D computerised system is in principle incapable of discerning.

Several authors (including Abdul-Rahman et al., 2012; Khoo, 2012; Soon, 2012; Stoter et al., 2012b; Wang et al., 2012; Ying et al., 2012; Zhao et al., 2012; Abdul-Rahman et al., 2011; Stoter et al., 2011; van Oosterom et al., 2011; Hassan et al., 2010; Chong, 2006; Stoter and van Oosterom, 2006; Valstade, 2005; Stoter, 2004; Stoter et al., 2004) have demonstrated that indeed 3D representations of airspace and subterranean parcels are currently required given that $2 \mathrm{D}+$ half representations are unable to handle 3D measurements, spatial queries, or visualisation. As reviewed in section 3.3, 3D cadastral technology has emerged recently. There has been considerable research over the past decade on the founding aspects of 3D cadastres, and some pilot studies have been accomplished so far. Victor Khoo (2012) summarised the main aims to be achieved in implementing a 3D cadastral system, as follows:

- To adopt an official and authoritative source of 3D cadastral survey information;

- To adopt open source format for data exchange and dissemination;

- To adopt international standards in data modelling; 
- To design a smart data model that supports "3D parcels" ( $v d$. definition in section 3.4.1);

- To automate cadastral survey data processing and official approval;

- Finally, to introduce a $4^{\text {th }}$ dimension related to time towards a 4D data model.

\subsection{D cadastral issues}

3.2.1 3D spatial and semantic information: In the light of the international standard ISO 19152, on the Geographicinformation Land Administration Domain Model (LADM), the notion of $3 \mathrm{D}$ cadastre with $3 \mathrm{D}$ parcels has to be understood in the broadest possible sense. What a $3 \mathrm{D}$ parcel exactly is, or could be, may well depend upon both the legal and organisational context of each specific country (or state/province). The broad meaning of a 3D parcel includes land and water spaces, both above and below surface. Nevertheless, a formal definition can be given as follows: "a $3 \mathrm{D}$ parcel is defined as the spatial unit against which one or more homogeneous and unique rights (e.g. ownership right or land use right), onus or restrictions are associated to the whole entity", as included in a Land Administration system (ISO 19152, 2012).

The term "homogenous" above means that the same combination of rights equally applies to the whole 3D spatial unit; furthermore, "unique" means that it is the largest spatial unit for which the above is true. Hence, making the unit any larger would result in the combination of rights not being homogenous; making the unit smaller would result in at least 2 neighbour 3D parcels with the same combinations of rights.

A 3D parcel always refers to a "legal object" describing simultaneously a "part of the space". Thus, in general property cadastres there are two different types of objects: the legal and the spatial ones. Often there is a direct relationship between a legal and a real world spatial object. It is the spatial object that in turn may be also described in 3D. More precisely, the focus in the context of 3D cadastres is on $3 \mathrm{D}$ parcels understood as "spaces of legal objects".

Accurate collection methods of $3 \mathrm{D}$ spatial data are required so that relevant data acquired at a specific time may be incorporated in a 3D data structure. Spatial data may refer to information such as on: the ownership number; the parcel's unique identifier; the parcel's geometric shape and area; if it is the case, on the footprint of manmade constructions, e.g. buildings, within the parcel; building geometry; each building's floor area (Hassan and Abdul-Rahman, 2010, cited in AbdulRahman et al., 2012). As far as semantic information is concerned, this has to be rich enough in order to provide a description about the parcel as detailed as possible, such as: owner identity, e.g. name and national insurance number; parcel history; number of physical components; type of lease; if it is a building, number of floors, or volume space. In 3D modelling, implicit or explicit geometry may well be used to generate the 3D model itself. With this regard, the integration of Building Information Models (BIM) can also help in data collection process, though this should only be carried out if the integration of both CityGML and IFC standards can be achieved (AbdulRahman et al., 2012). The spatial unit package defines spatial units as being 2D (land parcels) or 3D (space), buildings, or utility networks. These include in turn topological, polygon, line, point, and text spatial units (ISO 19152, 2012).
3.2.2 Marine cadastre: This naturally makes sense in countries sharing borders within water bodies, e.g. oceans or lakes. Marine environment may consist of activities related to territorial waters control, sea navigation, fishing, tourism, and oil or gas exploration. As a fact of matter, in the specific case of Portugal, an historical maritime country, this type of cadastre is of most relevance. It is in fact the largest European country in terms of territorial waters, and thus this specific topic needs further investigation in the context of such a maritime country.

The marine space is slightly different from that of land and introduces complexities involving, for instance, rights and responsibilities that vary in time. These facts require the collection of sorts of spatial data different from those landbased (Abdul-Rahman et al., 2012).

Marine objects can be described as: sea surface, water volume, seabed, and sub-seabed objects - which can be demarcated up to a country's Economic Exclusive Zone (Ng'ang'a et al., 2004). Typically the rights for marine cadastre are overlapping in nature that makes the demarcation of marine parcels a complex issue.

3.2.3 Underground utility networks: Possibly because underground utility networks are overall owned by government agencies in most countries, these are not seen to constitute real parcels to be included in cadastres. Moreover, underground utility networks are typically developed in 2D thus creating beforehand enormous overlay difficulties in terms of volumetric spatial data.

Several authors, including Abdul-Rahman et al. (2011), Cheng (2006), among others, have identified 3D underground utility networks to be one of the most important themes in a 3D cadastral database. Such a database is considered the fundamental basis for a sustainable underground usage management, enabling local authorities to establish exact locations for the various utility networks in a given urban area. 


\subsection{An overview of 3D modelling approaches in cadastral systems}

Further to the International Federation of Surveyors (FIG) congress in April 2002, some work has been devoted to 3D aspects of cadastral registration systems both in a fundamental way and at an international level. This has been done mainly in the context of a working group set up as a joint sub-group of Commission 3 and Commission 7 of FIG - which is in turn subdivided into three sections dealing with the legal, institutional, and technical aspects of $3 \mathrm{D}$ cadastre respectively.

The joint sub-group above has promoted so far three international workshops: Netherlands, Nov 2001 (www.gdmc.nl/events/3dcadastres2001); Netherlands, Nov 2011 (3dcadastres2011.nl); China, Oct 2012 (www.cadastre2012.org). A wide range of papers have been presented throughout those workshops on $3 \mathrm{D}$ modelling approaches towards what has been defined as "smart cadastre" that supports 3D parcels (Khoo, 2012).

Before 3D approaches towards 3D cadastres were actually conceived and implemented, there was initial work some time ago reviewing the status of different cadastres across the world. Back in 2004, Steudler et al. (2004) started a worldwide comparison of cadastral systems. In the context of a comparative analysis on the cadastral systems in the European Union (EU), Manthorpe (2004) carried out a review on the UK really. In turn, starting off from a comparative analysis of cadastral systems across the European continent, Valstade (2005) undertook a similar study in Norway. Yavuz (2005) carried out possibly the first comparative analysis of cadastral systems in European Union (EU) countries according to basic selected criteria.
In the meantime, there has also been considerable research for more than a decade now on the foundations of 3D geospatial data-structures as a whole, not necessarily towards 3D cadastral systems. Several authors have worked specifically on the identification of possible topological relationships in the 3D context and their validation. For instance, by considering twodimensional topology and modelling as a starting point, Gröger and Plümer (2005) took it further in order to be able to deal with topological concepts and models that are necessary to represent three-dimensional urban objects in a geographical information system (GIS). Ellul et al. (2005) initially derived a generic topological datastructure for $3 \mathrm{D}$ data, and defined the fundamental requirements for the implementation of topology in 3D GIS (Ellul et al., 2006). Further to the need for efficient and scalable techniques for storage, validation and query of 3D models in terrestrial data management, Kazar et al. (2008) focused on the problem of validation of 3D geometries, and presented an Oracle's data model for storing 3D geometries. Verbee and Si (2008) employed "constrained Delaunay tetrahedralisation" to check the validity of a single 3D polyhedron. Ellul et al. (2009) reviewed the 9-intersection framework for boundary representation in 3D GIS, and then outlined modifications to that structure to improve binary relationship query performance. Brugman et al. (2011) developed a series of topological rules to validate a 3D topology structure for a 3D space partition. Having in mind their application to $3 \mathrm{D}$ cadastre in particular, Thompson and Van Oosterom (2011a, 2011b) in turn extended Brugman et al.'s rules to axiomatic definitions to validate a $3 \mathrm{D}$ parcel and its relationship with adjacent $3 \mathrm{D}$ parcels within a space partition. By defining an axiomatic characterisation of 3D city models, Gröger and Plümer (2011a) worked on consistency checking tools to assess the suitability of spatial data for their applications.

As far as 3D cadastre in particular is concerned, Jantien Stoter and van-Oosterom (Stoter, 2004; Stoter and van-Oosterom, 2006) have analysed the needs and opportunities for a 3D cadastre. Starting from the Dutch cadastral reality, these authors set up one of the very first frameworks for modelling both 2D and $3 \mathrm{D}$ cadastral situations in a worldwide context, and developed a general prototype model for a 3D cadastre. Karki et al. (2011) specifically discussed geospatial data validation in $3 \mathrm{D}$ cadastre including a single $3 \mathrm{D}$ parcel and its relationships with other 3D parcels. Further to Verbee and Si (2008), Brugman et al. (2011), Thompson and Van Oosterom (2011), and Karki et al. (2011a), Zhao et al. (2012) proposed a novel method towards the validation of spatial relationships among 3D parcels, by identifying either correct or even incorrect topological relations in 3D. Furthermore, geovisualisation aspects in 3D cadastre have been also tackled. Wang et al. (2012) have been working on the visualisation principles in 3D cadastres and investigated which variables among visual variables are appropriate for geovisualisation of 3D legal units in a $3 \mathrm{D}$ cadastre system. In 2011, Oosterom et al. accomplished a worldwide inventory of the status of 3D cadastres in 2010 and stated what the expectations were for 2014. 
Other authors have developed in turn relevant work on the extension of 3D GIS to 3D cadastre. 3D GIS offers indeed some techniques that can be directly applied in $3 \mathrm{D}$ cadastre - for instance, 3D GIS provides proper methods for the representation of geometry of 3D cadastral objects and to associate to them property rights, semantics, and transaction attributes. Nevertheless, other techniques should be improved in order to be able to deal with management operations within 3D land administration. This is mainly because 3D GIS and 3D cadastre objects are different. For instance, Gröger and Plümer (2011b) extended the axiomatic characterization of 3D surfaces proposed by them (Gröger and Plümer, 2011a), which guaranteed consistency between geometry and topology, to the case of "handles" (e.g. tunnels, bridges, or arcades); by doing this, the authors closed the gap between the global topological definition of handles in surfaces and the local definition of semantical handle objects in GIS. Frédéricque et al. (2011) presented a benchmark exercise in which an architecture, combining both desktop GIS applications with server based RDBMS, was used to implement different scenarios for a 3D Cadastre (full 3D and hybrid); results obtained by the authors illustrate how possible it is to combine advanced CAD and GIS technologies to create and update intelligent objects corresponding to both 3D urban features and 3D property units. Ying et al. (2012) applied 3D GIS techniques to 3D cadastre in urban environment as an attempt to build the bridge and fill the gap between urban simulation and urban space management; details of such application were elaborated through three main aspects: 3D data and 3D modelling, 3D simulations and 3D visualisation, practice and decision-making support.

Furthermore, a remark should be done on the increasing prevalence of building information models (BIM). New technologies on BIM are continuously being developed which means that we can expect to see very detailed building models available in the planning stage. Consequently, these models appear to be useful to generate 3D volumes for properties (Frédéricque et al., 2011; Smith, 2012).

More recently, various pilot 3D cadastre systems have been developed and tested for the specific cadastral context of some countries, like: Australia (Karki et al., 2011b), Brazil (Barrosde-Souza, 2011), China (Guo, 2011), Korea (Jeong et al., 2011), Malaysia (Abdul-Rahman et al., 2012), Russia (Vandysheva et al., 2011), Singapore (Khoo, 2012; Soon, 2012), or The Netherlands (Stoter et al., 2011, 2012b).

Finally, as far as Portugal's cadastral context is concerned, Hespanha et al. (2006) worked on the evaluation of an initial FIG core cadastral model (Lemmen et al., 2003) by applying it to Portugal's cadastre. Based on that previously proposed standard, an object oriented, conceptual model for the cadastral domain was then adapted to the Portuguese cadastre and associate real estate registry Registo Predial. Their approach however covered essentially the $2 \mathrm{D}$ reality and needs to be taken further towards 3D cadastral modelling purposes.

\subsection{A 3D cadastral approach for Portugal's cadastre - some case studies}

Recent encouraging governmental decisions described in section 2.3 are absolutely vital when envisaging a centralised cadastral management system. Nevertheless, 3D aspects of cadastral data towards a possible 3D cadastral system have not been covered in this project.
As elsewhere in the world, many examples can be identified in Portugal's context where the 2D cadastre is limited. For instance, the work being currently accomplished by the Coimbra city council $\left(\mathrm{CMC}^{6}\right)$ can be placed amongst the initiatives undertaken by some state institutions as that described in section 2.3 above.

Preliminary discussions between the authors and some CMC staff (particularly from its cadastre and land management office $^{7}$ ), allowed the identification of some case studies. For the purposes of this paper, three of them were chosen in order to demonstrate the pertinence of a 3D cadastral modelling approach. They correspond to different somewhat complex cadastral situations detected in the city Coimbra, however similar cases can be found across the country.

\subsubsection{Case study 1 - flats shared by different buildings:}

This case study refers to a very much common situation especially within the medieval pattern of ancient neighbourhoods that characterise most of the Portuguese towns and cities. There are instances where a flat though mostly contained by a given building happens to incorporate a room that physically belongs to a next-door building. In other words what happens is that, physical structures of buildings and "their" flats do not actually coincide.

For illustration purposes, let us have a look at the hypothetical situation depicted in Figure 5 below. A flat on the first floor left of the light-grey building (represented by the dashed black line), is supposingly contained within this building. However, it includes a room that physically happens to be located inside the next-door white building. Such a situation turns to be even more complex for it cannot be visualised from outside. How can such an unexpected case be handled by a computerised cadastral system?

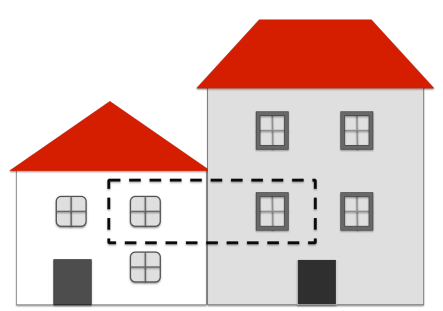

Figure 5. Complex 3D cadastre occurrences in the medieval Coimbra downtown (Portugal): a flat shared by two buildings.

3.4.2 Case study 2 - underground property unit underneath several properties: In this case, the issue is to some extent related to that in case study 1 above: property units and the physical infrastructure of buildings do not coincide.

The situation depicted in Figure 6 below relates do an underground communal garage that does not coincide with the underground infrastructure of the building it "belongs to". According to the Portuguese law, ownership rights over a given real estate on the ground also apply to the underground area underneath that property. As it can be seen in Figure 6, those rights do not apply to the white building on the left for its underground area is taken by the communal garage that actually belongs to the light-grey building on the right. Again, as in case study 1 , such a situation turns to be even more complex for it cannot be visualised from outside. How can a computerised

\footnotetext{
${ }^{6}$ CMC - Câmara Municipal de Coimbra.

${ }^{7}$ GCS - Gabinete de Cadastro e Solos.
} 
cadastral system be capable of handling exceptions to the cadastral law like this one?

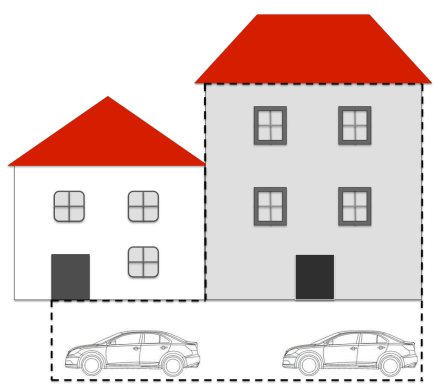

Figure 6 - Complex 3D cadastre occurrences in Coimbra (Portugal): underground garage underneath a next-door building.

3.4.3 Case study 3 - private property over public space: Finally, a third situation is presented. This case study covers another exception to the cadastral law in Portugal. As a principle, according to the Portuguese cadastral law, ownership rights over a given real estate above ground also apply to the overground area underneath that property.

In Figure 7 below, the block of apartments illustrated is an arch building over an urban road. This constitutes an exception to the legal principle above. Indeed, condominium ownership rights cannot be applied to the overground area underneath the arch building since this constitutes public domain. Once again, how can a computerised cadastral system be capable of handling exceptions to the cadastral law like this one?

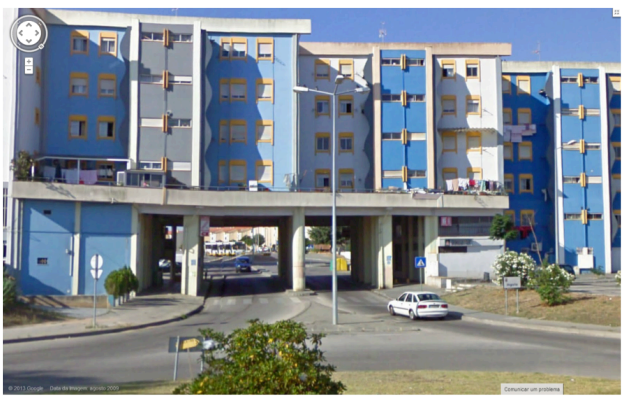

Figure 7 - Complex 3D cadastre occurrences in Coimbra

(Portugal): block of apartments (property units) over an urban road (public space) - source: GoogleEarth.

\section{CONCLUSIONS}

At the centre of any land management operation there are private/state property issues. That is why real estate cadastre and cadastral systems play such an important role in property taxation, property conveyance, and urban/regional planning or any other administrative purpose. The statements above show how pertinent this topic is; indeed, widely recognised to be the basis of a healthy economy.

All cadastres implemented so far across the world typically implement a 2D modelling approach. As reviewed in this paper, it has been proved in the literature that there are instances though of multiple use of space, with stratified property rights in land, where traditional 2D cadastre is not able to reflect in the third dimension the spatial information on those rights. The main reasons of the need for a more sophisticated modelling approach towards 3D cadastral systems of land registration may be summarised as follows:
- Materialisation of legal ownership concepts within a 3D geometry structure - particularly needed to handle exceptional 3D occurrences of the cadastral law;

- 3D visualisation capabilities, especially of occurrences above, for both authorities and general public.

As far as Portugal is concerned - our ultimate interest - a centralised distributed cadastral management system was conceived (SiNErGIC), though not implemented yet. Such a system is based on a 2D model approach. One of the main conclusions of this preliminary work is that it is believed that there is room for the investigation on the suitability of a 3D modelling approach instead. This should not be confined only to topological-geometric representations but should also be extended further in order to be able to incorporate the legal/administrative component, as generally recommended in Lemmen et al. (2010) and Lemmen (2012).

As stated in section 3.3 above, it seems that previous work developed by Hespanha et al. (2006) should be considered as the starting point and taken further towards a prototype of a 3D cadastral model for Portugal's context. We strongly believe that this can be achieved by considering the international standard ISO 19152 and by conveniently adapting it in order to incorporate the Portuguese cadastral law. The final result should be a 3D cadastral model capable of handling the overall multipurpose cadastral reality in Portugal.

Previous related work summarised in section 3.3 should also be of interest and worthy of being considered. However, further investigation is required in order to evaluate to what extent the approaches reviewed suit Portugal's cadastral context and what the eventual needed adaptations are. In addition, even before a prototype is developed, a step towards a strategic vision should be the identification of cadastre information users and understand their needs. A second step should be to understand how $3 \mathrm{D}$ cadastre data are actually acquired in the field and processed thereafter. Finally, further to the design and implementation of a possible 3D cadastral prototype, experiments should be performed taking into consideration some case studies, such as those illustrated and described in this paper, section 3.4.

\section{REFERENCES}

Abdul-Rahman A, Van Oosterom P, Chee Hua T, Sharkavi K H, Duncan E E, AzriI N, Hassan I, 2012. 3D Modelling for Multipurpose Cadastre. $3^{\text {rd }}$ International Workshop on $3 D$ Cadastres: Developments and Practices, Shenzhen, China.

Abdul-Rahman A, Hua T H, Van Oosterom P, 2011. Embedding 3D into Multipurpose Cadastre. FIG working week, Marakech, Marroco.

Barros-de-Souza G H, 2011. Método de Modelagem da Parcela Espacial para o Cadastro Tridimensional ( $\mathrm{PhD}$ thesis, not published). Universidade Estadual Paulista, São Paulo, Brazil.

Brugman B, Tijssen T, Van Oosterom P, 2011. Validating a 3D topological structure of a 3D space partition. In Geertman S C $\mathrm{M}$ et al. (eds.) Advancing Geoinformation Science for a Changing World, Lecture Notes In Geoinformation and Cartography 1: pp. 359-378.

Chong C S, 2006. Toward a 3D Cadastre in Malaysia - An Implementation Evaluation. Delft University of Technology, 110 . 
Ellul C, Haklay M, Bevan T, 2005. Deriving a Generic Topological Data Structure for 3D Data. In Proceedings of GISRUK 2005 - 13th Annual Conference.

Ellul C, Haklay M, 2006. Requirements for Topology in 3D GIS. In Transactions in GIS 10(2): pp. 157-175. Wiley Online Library.

Ellul C, Haklay M, 2009. Using a B-Rep Structure to Query 9Intersection Topological Relationships in 3D GIS - Reviewing the Approach and Improving Performance. In $3 D$ Geoinformation Sciences, Lecture Notes in Geoinformation and Cartography, Part II, pp. 127-151.

FIG, 1995. The FIG Statement on the Cadastre. Technical Report Publication No. 11, Federation International de Géomètres, Commission 7 [online]. Available from www.fig.net/commission7/reports/cadastre/statement_on_cadast re.html (30 Oct 2012).

Frédéricque B, Keith, Raymond K, Van Prooijen K, 2011. 3D GIS as Applied to Cadastre - a Benchmark of Today's Capabilities. FIG Working Week, Marrakech, Morocco.

Gröger G, Plümer L, 2005. How to Get 3D for the Price of 2-D - Topology and Consistency of 3D Urban GIS. Geoinformatica 9.2, pp. $139-158$.

Gröger G, Plümer L, 2011a. How to achieve consistency for 3D city models. Geoinformatica 15, 137-165.

Gröger G, Plümer L, 2011b. Topology of Surfaces Modelling Bridges and Tunnels in 3D GIS. Computers, Environment and Urban Systems, 35(3), pp. 208-216.

Guo R, Ying S, Li L, Luo P, He B, Zhao Z, 2011. 3D Cadastre in China - a case study in Shenzhen city. In Proceedings of $2^{\text {nd }}$ International Workshop on $3 D$ Cadastres. Delft -The Netherlands, November, pp. 292-309.

Hassan M I, Abdul-Rahman A, 2010. Malaysian Integrated 3D Cadastre Registration System. FIG Congress, Sidney, Australia, pp.14.

Hespanha J P, Van Oosterom P, Zevenbergen J, Paiva-Dias G, 2006. A Modular Standard for Cadastral Domain - Application to the Portuguese Cadastre. Computers, Environment and Urban Systems, 30(5), pp. 562-584.

IGP, 2012. Instituto Geográfico Português, www.igeo.pt (28 Oct 2012).

ISO/TC211, 2012. Geographic information - Land Administration Domain Model, ISO/FDIS 19152.

Jeong D, Kim T, Nam D, Li H, Cho H, 2011. A Review of 3D Cadastre Pilot Project and the Policy of 3D NSDI in the Republic of Korea. In Proceedings of 2nd International Workshop on $3 D$ Cadastres, Delft, The Netherlands, pp. 311332.

Karki S, Thompson R, McDougall K, 2011a. Data validation in 3D cadastre. In Developments in 3D Geoinformation Sciences, Lecture Notes in Geoinformation and Cartography, pp. 92-122.

Karki S, Thompson R, McDougall K, Cumerford N, Van Oosterom P, 2011b. ISO Land Administration Domain Model and LandXML in the Development of Digital Survey Plan Lodgement for 3D Cadastre in Australia. In Proceedings of $2^{\text {nd }}$
International Workshop on $3 D$ Cadastres, Delft, The Netherlands, pp. 65-84.

Kazar B M, Kothuri R, Van Oosterom P, Ravada S, 2008. On Valid and Invalid Three-Dimensional Geometries. In Van Oosterom P, Penninga F, Zlatanova S, Fendel E (eds.) Advances in $3 D$ Geoinformation Systems, Berlin, Springer.

Khoo V H S, 2012. Towards "Smart Cadastre" that Supports 3D Parcels. $3^{\text {rd }}$ International Workshop on $3 D$ Cadastres: Developments and Practices, Shenzhen, China.

Lemmen C, Van der Molen P, Van Oosterom P, Ploeger H, Quak W, Stoter J, Zevenbergen J, 2003. A Modular Standard for the Cadastral Domain. In Proceedings of $3^{\text {rd }}$ International Symposium on Digital Earth, Brno, Czech Republic, pp. 399419.

Lemmen C, Van Oosterom P, Thompson R, Hespanha J P, Uitermark H, 2010. The Modelling of Spatial Units (Parcels) in the Land Administration Domain Model (LADM). FIG Congress 2010, Sydney, Australia.

Lemmen C, 2012. A Domain Model for Land Administration. Publications on Geodesy, 78. Delft, The Netherlands, NCG.

Manthorpe J, 2004. Comparative Analysis of Cadastral and Land Administration Systems in the United Kingdom. Comparative Analysis on the Cadastral Systems in the European Union. The European Union Permanent Committee on Cadastre.

Mendes I P, 2003. Estudos sobre Registo Predial. Coimbra, Portugal, Almedina.

Ng'ang'a S, Sutherland M, Cockburn S, Nichols S, 2004. Toward a 3D marine cadastre in support of good ocean governance: a review of the technical framework requirements. Computers, Environment and Urban Systems, 28(5), pp. 443470 .

PCM (Presidência do Conselho de Ministros), 2006. Resolução do Conselho de Ministros nr. 45. Diário da República Portuguesa, Série I-B, $\mathrm{Nr}^{\circ} .86,4$ de maio.

PCM (Presidência do Conselho de Ministros), 2012a. Resolução do Conselho de Ministros nr. 56. Diário da República Portuguesa, Série I, $\mathrm{Nr}^{\circ} .129,5$ de julho.

PCM (Presidência do Conselho de Ministros), 2012b. Resolução do Conselho de Ministros nr. 70. Diário da República Portuguesa, Série I, Nro $.164,24$ de agosto.

Silva M J, Bessa M I, Machado V, Clode L, 2005. Breves notas sobre os procedimentos legais conducentes à primeira inscrição no registo predial português, e à regularização fundiária no âmbito das operações urbanísticas". XV Congresso Internacional de Direito Registral, Fortaleza, Brasil.

Smith J A, 2012. Building Information Model - A Contractors Perspective. In International Federation of Surveyors, article of the month - June.

Soon K H, 2012. A conceptual framework of representing semantics for $3 \mathrm{D}$ cadastre in Singapore. $3^{\text {rd }}$ International Workshop on 3D Cadastres: Developments and Practices, Shenzhen, China. 
Steudler D, Rajabifard A, Williamsin I, 2004. A worldwide comparison of cadastral systems (Working sheet, not published). The 'Permanent Committee on GIS Infrastructure for Asia \& the Pacific' (PCGIAP) Working Group 3; The 'International Federation of Surveyors ' (FIG) - Working Group 7.

Stoter J, 2004. 3D Cadastre. In Publications on Geodesy, 57, Delft, The Netherlands, NCG.

Stoter J, Van Oosterom P, Ploeger J, Hendrik D, Aalders H, 2004. Conceptual 3D Cadastral Model Applied in Several Countries in TS25 - Appropriate Technologies for Good Land Administration II - 3D Cadastre. FIG Working Week, Athens, Greece.

Stoter J, Van Oosterom P, 2006. 3D Cadastre in an International Context: Legal, Organizational, and Technological Aspects. Taylor \& Francis, Boca Raton (FL), USA.

Stoter J (2011): Geoprofessionals should look outside their own box [online]. GIM International, 25(12). Available from http://www.gim-international.com/issues/articles/id1794Geoprofessionals_Should_Look_Ouside_Their_Own_Box.html (20 Nov 2012).

Stoter J, Ploeger H, Louwman W, Van Oosterom P, Wünsch B, 2011. Registration of 3D Situations in Land Administration in The Netherlands. In Proceedings of $2^{\text {nd }}$ International Workshop on 3D Cadastres, Delft, The Netherlands, pp. 271-290.

Stoter J, Beets J, Ledoux H, Reuver M, Klooster R, Janssen P, Penninga F, 2012a. Towards mainstream geographical data [online]. Geospatial World Forum, Amsterdam, The Netherlands. Available from http://beta.geospatialworld.net/Regions/ArticleView.aspx?aid=2 $\underline{5159}$ (21 Nov 2012).

Stoter J, Van Oosterom P, Ploeger H, 2012b. The phased 3D cadastre implementation in the Netherlands. $3^{\text {rd }}$ International Workshop on $3 D$ Cadastres: Developments and Practices, Shenzhen, China.

Thompson R, Van Oosterom P, 2011. Modelling and validation of $3 \mathrm{D}$ cadastral objects. UDMS, Delft, The Netherlands.

Thompson R, Van Oosterom P, 2011. Axiomatic Definition of Valid 3D Parcels, potentially in a Space Partition. In Proceedings of the $2^{\text {nd }}$ International Workshop on $3 D$ Cadastres, Delft, The Netherlands.

Valstade T, 2005. 3D Cadastres in Europe - Norway. Cadastral Infrastructure, Bogota, Colombia.

Vandysheva N, Ivanov A, Pakhomov S, 2011. Design of the 3D Cadastre Model and Development of the Prototype in the Russian Federation. In Proceedings of the $2^{\text {nd }}$ International Workshop on 3D-Cadastres, Delft, The Netherlands, pp. 355375 .

van Oosterom P, Stoter J, Ploeger H, Thompson R, Karki S, 2011. World-wide Inventory of the Status of 3D Cadastres in 2010 and Expectations for 2014. FIG Working Week, Marrakech, Morocco.

Verbee E, Si H, 2008. Validation and storage of polyhedra through constrained Delaunay tetrahedralization. In Cova $\mathrm{T} \mathrm{J}$ ET AL. (eds.) GIScience 2008, LNCS 5266, pp. 354-369.
Wang C, Pouliot J, Hubert F, 2012. Visualization principles in 3D cadastre: a first assessment of visual variables. $3^{\text {rd }}$ International Workshop on 3D Cadastres: Developments and Practices, Shenzhen, China.

Ying S, Guo R, Li L, He B, 2012. Application of 3D GIS to 3D cadastre in urban environment. $3^{\text {rd }}$ International Workshop on 3D Cadastres: Developments and Practices, Shenzhen, China.

Yavuz A, 2005. A Comparative Analysis of Cadastral Systems in the EU Countries According to Basic Selected Criteria. "From Pharaohs to Geoinformatics", FIG Working Week 2005 and GSDI-8, Cairo, Egypt.

Zhao Z, Guo R, Li L, Ying S, 2012. Topological relationship identification in $3 \mathrm{D}$ cadastre. $3^{\text {rd }}$ International Workshop on $3 D$ Cadastres: Developments and Practices, Shenzhen, China.

\section{ACKNOWLEDGEMENTS}

The authors want to express their gratitude to the Portuguese foundation for science and technology (FCT - Fundação para a Ciência e Tecnologia), which partially supported this research through the project grant PEst-C/ EEI/UI0308/2011. 